\title{
REFERENCES:
}

1. Зайцева М.О. Судовий дискурс: мовленнєві стратегії і тактики, мовні засоби вираження конфрлікту. Первый независимый научный вестник. № 6. 2016. С. 74-78.

2. Коваль Н.Є. Мовні засоби аргументації в юридичному дискурсі (на матеріалі англомовних законодавчих та судових документів) : автореф. дис. ... канд. філол. наук. Одеса, 2007. 22 с.

3. Кожемякин Е.А. Юридический дискурс как культурный феномен: структура и смыслообразование. URL: http://konference.siberia-expert.com/publ (дата звернення: 18.03.2021).

4. Atkinson J.M., Drew P. Order in Court: the Organization of Verbal Interaction in Judicial Settings. Atlantic Highlands, New Jersey : Humanities Press, 1979. 275 p.

5. Cotsirilos G.J. Meeting the Prosecution's Case: Tactics and Strategies of Cross-Examination. Journal of Criminal Law and Criminology. 62/2. 1971. P. 141-152.

6. Cotterill J. Interpersonal Pragmatics. URL: https//books.google.com.ua (дата звернення: 18.03.2021).

7. Coulthard M., Johnson A. An Introduction to Forensic Linguistics: Language in Evidence, London \& New York : Routledge, 2007. 237 p.

8. Dijk T.A. van, Kintsch W. Strategies of Discourse Comprehension. New York : Academic Press, 1983. 413 p.

9. Gifis S.H. Law Dictionary. New York: Barron's Educational Series [5 $5^{\text {th }}$ edition], 2003.

10. Grice P. Logic and Conversation. Syntax and Semantics. Vol. 3. Speech Acts. New York Academic Press, 1975. P. $75-115$.

11.Gunlogson C. Declarative Questions. URL: https://journals.linguisticsociety.org/proceedings/index.php/SALT/ article/viewFile/2860/2600 (дата звернення: 18.03.2021).

12. Leech G.N. Principles of Pragmatics. London : Longman, 1983. 250 p.

13. Opeibi T. Language Countertrading in Courtroom Exchanges in Nigeria: a Discoursive Study. International Journal of Applied Linguistics and English Literature. 1. № 5. 2012. P. 49-63.

14. Schegloff E.A., Sacks H. Openings and closings. Semiotica. 7. 1973. P. 289-327.

15. Tajabadi A., Dowlatabadi H., Mehri E. Grice's Cooperative Maxims in Oral Arguments: the Case of Dispute Settlement in Councils in Iran. Procedia - Social and Behavioral Sciences. 98. 2014. P. 1859-1865.

16. Zhyhadlo O. Pragmatic Features of Lawyer-witness Interaction in English Courtroom Discourse. Наукові записки Національного університету «Острозька академія». Серія «Філологія»: науковий журнал. Острог : Вид-во НаУОА. Вип. 8 (76). 2019. С. 7-10.

UDC 811:111

DOI https://doi.org/10.32782/tps2663-4880/2021.15.12

\section{ANTHROPOCENTRIC FRAMEWORK OF ENGLISH LANGUAGE AND ITS STYLISTIC REPRESENTATION}

\section{АНТРОПОЦЕНТРИЧНА ФРЕЙМОВІСТЬ АНГЛІЙСЬКОЇ МОВИ ТА ЇЇ СТИЛІСТИЧНА РЕПРЕЗЕНТАЦІЯ}

\author{
Lazebna N.V., \\ orcid.org/0000-0001-5886-693X \\ Candidate of Philological Sciences, \\ Associate Professor at the Department of Translation Theory and Practice \\ Zaporizhzhya Polytechnic National University
}

\footnotetext{
The article focuses on the language and its nature. Shifting from general terms, the article considers the English language and concentrates on its specific anthropomorphic framework. The language embodies all deep layers of the spiritual life of the people, their historical memory, intellectual and mental activities. Language is a means of conveying to people true values and relationships. Moreover, symbols of the language are related to factual information transmitted using speech. The concept of conventionality is important for the development or formation of human understanding for further verbalization. Examining the work of Lewis, we can claim that the author has turned to explanations of the approach to the study of the natural properties of language. According to his studies, the convention plays a key role. He uses his game-theoretic concept of the convention to indicate actual conditions of language and develops the concept of the language culture. Linguistic culture is reliable support in the expression of independence of thought, the development of human feelings, ethical norms, and the way of social behavior. Language culture is associated with the ability to speak and write
} 
correctly, to choose appropriate lingual means, to use means to express in the speech the ideas by the specific situation, purpose, and circumstances of communication. The success of human relationships depends on speech, which is an active and dynamic manifestation of human activity and reflects human experiences. Language for culture means the same thing as the central nervous system for humans does. A person can speak several languages, depending on his abilities and aspirations, but his mother tongue should demonstrate his skills and abilities. The language surrounding human beings is often inaccurate, and most importantly, often gives grounds to interpret what humans hear differently. Thus, the main purpose of accurate wording is to exclude the possibility of different interpretations of the content. However, in some cases, the speaker uses ambiguous statements on purpose. There is a need for abstract thinking because general statements are perceived in various ways and can be often misleading. Therefore, the words used should be correlated with the appropriate semantic non-ambiguity. The linguistic features are represented in different contexts and correlated with stylistic features of the English language.

Key words: language, formal structure, the concept of conventionality, convention, semantics, descriptivism, sensory perception, stylistic features of the English language.

Стаття базується на розумінні поняття про природу мови, адже мова уособлює всі глибинні пласти духовного життя народу, його історичну пам'ять, інтелектуальну і мисленнєву діяльність народу. Мова є засобом для передачі людям істинних цінностей та відносин. Крім того, мовні символи пов'язані з фрактичною інфрормацією, що передається засобами мови. Концепція умовності $€$ важливою для розвитку або формування розуміння людиною для подальшої вербалізації. Досліджуючи роботи Д. Льюїса, ми можемо визначити, що автор звертається до пояснень підходу до вивчення саме природних властивостей мови. За його словами, саме конвенційність (умовність) відіграє ключову роль. Дослідник використовує своє теоретико-ігрове поняття конвенційності, щоб вказати на умови фрактичності мови та розвиває поняття мовної культури. Мовна культура - це надійний базис у вираженні незалежності думки, розвиненості людських почуттів, виробленні етичних норм, способу суспільної поведінки. Антроморфна фрреймовість англійської мови корелює мовні особливості з життям людини, екстраполює їх у глобальний культурний простір. Із культурою мови пов'язують уміння грамотно говорити й писати, майстерно добирати, вживати засоби для вираження мови відповідно до конкретної ситуації, мети і обставин спілкування. Успіх стосунків між людьми часто залежить від мовлення, яке є активним, динамічним виявом діяльності людини та відображає її досвід. Стверджується, що мова для культури - це те саме, що й центральна нервова система для людини. Мова, яку чують її носії та неносії, часто свідчить про явище багатозначності. Тлумачення змісту мовлення вказує на варіювання певного антропоморфного фррейму. Кореляція абстрактного мислення з висловленням у конкретній думці може вказувати на різне сприйняття слухачами певної інформації. Репрезентація лінгвальних особливостей мовців у різних контекстах корелюється зі стилістичними особливостями англійської мови.

Ключові слова: мова, формальна структура, концепція умовності, конвенція, семантика, дескриптивізм, сенсорне сприйняття, стилістичні особливості англійської мови.

In the modern world, there are still many arguments about the nature of language. What came the first, a hen or an egg? What came first, population or languages? Maybe, language is a structural phenomenon, which can exist beyond the world of humans? Such questions may trigger human minds and make them think about the nature of language.

Language is a means for people to transfer truth values and meanings to the world. Moreover, the language symbols are related to the factual information conveyed by the means of language. The condition of conventionality is important in the development or formation of human understanding of one or another concept, or their furtherexpression or verbalization [4].

Problem statement. Language mediates human feelings about the world and facilitates the process of human communication. Does the language go first, or do our ideas come to our minds first, this is also an interesting question? Why do we use language? To express our feelings and emotions, to convey our ideas to other language users, or to verbalize current intentions? There is a myriad of issues related to the potential of language realization or verbalization. Lewis correlates truth and language as two related concepts. Every sentence can be either true or false in terms of language or the whole world. If to interpret the main claim of Lewis, it is possible to say that true messages can be effective in one world, but cannot be true in another world, where these realities do not work. The goal of this article is to correlate the anthropocentric framework of the English language with its stylistic features and variety of contexts for representation thereof. Based on these claims, it is possible to say that languages are tools for a true depiction of the world. Within different contexts on various stylistic background, this research represents anthropomorphic features of the English language and their projection on different styles and genres by representing them in different contexts.

Of course, it is relevant to communicate in one common language background, understand the intentions of another speaker, and comprehend his target message. At this point, it is impossible to be a language connoisseur or at least an effective language speaker if there is an unclear language background.

Literature review. The main idea of Lewis in his work "Languages and Language" is that there is a strong relationship between populations and languages they speak. People transfer their ideas using words, or symbols, and they trust these symbols their intentions and ideas. There is an evident connection between the language symbols and the main message; conventional phrases and further produced sentences by the users. 
Any population deserves to speak their languages. What is the conventional transfer of the populations' ideas? Conventional thinking of people directly relates to their firm beliefs and actions. In other words, language is a perfect context and means of mediation between people, the representatives of one or another population. There is an interesting idea of Lewis, which underlines that the population $\mathrm{P}$ chooses the language $\mathrm{L}$ in case the language transfers or conveys truthful and reliable messages.

The claim about true messages can be rather dubious because not all claims we make can be true. Language can be a coordinating link between people. The speakers need a general and firm basis for the coordination of their communication process. In functional terms, the role of language is a coordinative one. Those, who use the language have a right to be understood by others. Once the population chooses the language $\mathrm{L}$, they become part of the linguistic conventionality. This claim is clear because if we use and speak one language, we understand each other, get meanings of our words, and realize deep senses.

If to refer only to the role of language as a perfect and effective means of communication, it is relevant to refer to the intuitive role of long sentences. Does it matter if the sentences are short or long? The intuitive potential of the speakers can identify or predetermine their language use. On the one hand, the length of the sentences does not matter. If a speaker uses a short sentence, does he say a true/false sentence? The number of words cannot determine the true/false essence of the sentence.

Lewis said that language users are "trying to win a bet or set a record, or feigning madness or raving for real, or doing it to annoy, or filibustering, or making an experiment to test the limits of what it is humanly possible to say and mean" [8]. If to explain the role of language and its true essence, with the help of symbols, it is possible to clarify that the speakers, actually speak language $L^{*}$, not L. A comprehensible and understandable form of a language depends on numerous factors.

On the one hand, the language is conventional, or "a platitude - something only a philosopher would dream of denying" [8, p. 166]. People assign certain meanings to the words. The words could have had other meanings, but these are people, who decide about certain meanings. Therefore, the principles of conventionality identify key concerns of the language speakers.

If to refer to the criticism about the work by Lewis, "language is conventional, when this is taken as the claim that facts about the meanings of expressions in our language are derived from the mutual knowl- edge of speakers concerning what members of a population mean or would mean by their utterances (or what they believe or would believe when making or hearing utterances), is not platitudinous" [8].

The author of the study appeals for the explanations of such an approach to the natural properties of language. Depending on the structural explanations and approaches to the language, it is relevant to claim that some grammars are more natural and universal than others. Whether grammar plays a central role in language formation and cognition, is rather a dubious issue. For example, L is characterized by natural grammar. Supposedly, $L^{*}$ is not characterized by the functions of grammar. The language users would choose/ speak/use the language L and not L*. Grammar or formal structure is an advantage in face of the language, where there is no grammar or users do not stick to it firmly. There are various perspectives on the nature of language described by Lewis [8]. The assignment of meanings to certain words depends on the behavioral and sensory perception of the population.

Secondly, the interpretation or explanation of long sentences depends on attitude to their true meaning by the population. It is relevant to explain that first of all the speakers interpret propositions, which are in the center of the sentences. Truth-conditions of full sentences should be perceived by the public. If to explain the concept of conventionality, it is possible to claim that when people say that "the sun is shining brightly", they build this sentence on their belief and they say in such a way because they know that the sun is bright.

Lewis claims that there are many languages. There is a gradual transformation of true sentences, wellknown propositions for the population to development of truth conditions. Many of the languages described by formal semanticists are possible languages in this sense. Most possible languages, however, are not used by anyone. According to Lewis, this is where convention plays a key role. He uses his game-theoretic notion of the convention to specify under what conditions a possible language is an actual language, i.e. is used by a population of language users.

According to one of the critics, "Lewis's policy was to refrain (where possible) from saying anything about the best grammar of a language because he doubted the clarity and objectivity of our standards for evaluating grammars" [8]. Semantics is directly connected with truth conditions. The formality of semantics or true potential of sentences depends on the social/population beliefs.

If there is a convention to use formal structures, then the population believes in their charge of truth. Firstly, people refer to certain names to certain objects. 
In terms of one population, or the users of one language, people have a set of beliefs or common ideas and they follow their meaningful representations. Is there a similar representation of names/concepts in the English language as in other languages? If there is a semantic correlation between different concepts or generally accepted semantic maps? These and other concerns related to the mentality of one or another population. Lewis makes an emphasis on certain causal factors or determination element. Lewis claims, "The object at the end of a such-and-such causal chain that led to this idea" [8].

There should be a proper familiarity between the representatives of the population concerning any concept. For example, different speakers of one language may have a different understanding of different concepts. They may have certain characters in their minds, but these characters may have different contents. There can be different references between objects. It also depends on the mentality of a speaker, his surroundings, different related social factors, and so on [9]. The formal nature of language, on the one hand, predetermines mutual understanding of language users, but, on the other hand, it is rather difficult to mediate the process of communication in case of misconception or misunderstanding about the basic grammar structures or other formal elements. In terms of descriptivism, there can be different interpretations of some concepts.

According to this approach, "Funny' is less natural than 'Fatal'; 'Grue' is less natural than 'Green'. The idea of primitive naturalness does a great deal of work in Lewis's later philosophy, working to characterize such diverse things as physicalism, supervenience, law hood, and intrinsicness" [8]. There are certain assigned meanings of words. There is a relation to certain descriptions. The intermediate nature of references should be under consideration too. The language in terms of Lewis' consideration, first, mediates communication between speakers.

General discussion. It is possible to conclude that the language users focus on formalistic and theoretical structures the way they would build a house of bricks. From the first layer of word-formation elements, suffixes, and prefixes, to the highest level of texts and discourse, language users base their linguistic competence on a formalistic and structural basis, and then, they add semantics, stylistics, and pragmatics to enliven their communication.

Relationship between social interaction and language development

Language is a social phenomenon. The social aspect of language is a subject of consideration for many modern linguistic disciplines. Life-long lan- guage acquisition and learning of individuals causes studies, which focus on its social aspect. Language continues and develops throughout human life. There are many challenges and pitfalls in the process of language acquisition. From infants to adults, human beings come across linguistic difficulties. Understanding and usage of grammar, lexical units, and semantics depend on the social surrounding of language speakers. To solve this problem, it is relevant to talk to a child from the first months of his life. The speaking surrounding will make him speak early. A mother can comment on her daily actions while communicating with her baby. Further, she can read books to a child. The more a child hears, the more he repeats. He can reproduce sounds, words, and sentences.

"Vygotsky contends that as the child learns to use language, he or she gradually brings the socio-cultural world within him/herself" [5, p. 211].

Language acquisition is a difficult process, which depends on his physiological, psychological abilities, and social surrounding. It takes place in the language surrounding [7, p. 45]. If to consider this relationship in wider terms, it is possible to claim that if an individual is surrounded by a foreign language environment, it influences his language acquisition or the process of communication. Native words may overlap foreign ones, or language speakers of one language can influence the accent of language speakers of another language. There is an evident relationship between social interaction and language development. Further, these extralinguistic factors will be projected on the stylistic features of the English language.

Stylistic usages of English in poetry, journalese, and advertising

Language of advertising: ads are created to stimulate customers to spend their money. Thus, advertising appeals to the hearts and wallets of the target audience. Ads should act instantaneously similar to lightning. Small words and phrases are often used as independent sentences; if clauses are often used to explain a logical bound of the ad (Example 1); a list of adjectives is another common stylistic device used in ads (good, free, fresh, wonderful, etc) (Example 2); imperative clauses (Example) are also relevant to this genre.

Grammatical devices make ads closer to the audience, translating them from written into oral manner. In other words, written ads should be memorable for the audience as if they heard them every day. Grammatical simplicity (Example 4) and easy perception of ads is the right way to gain a wider audience [1]. Moreover, definite articles play 
an important semantic role in ads. They are widely used in ads and create a 'particularity of reference' (Example 5). Of course, the usage of specific grammatical devices is not enough to reach success in advertising. Creative writing, such as usage of puns, polysemy, alliteration, metaphors, etc is an integral part of a successful ad.

For example:

The flavor of a Quaver is never known to waver-rhyming.

American Home has an edifice complex - pun.

The more we progress, the better you advancepun [1].

Aurally, the audience is attracted and thus memorizes ads. As a result, a vivid language of advertising can be also met in other social spheres of life. Political leaders use some methods of the language of advertising in their promotional campaigns; journalists try to draw the attention of the readers to their articles by the usage of creative writing and a high level of communication. Still, there are numerous techniques used by advertisers, but all of them are directed at showing the perfectness and superiority of the advertised product. For example, the usage of 'the weasel claim' is directed at showing the audience superiority of the product. As it is known, "a weasel word is a modifier that practically negates the claim that follows. The expression "weasel word" is aptly named after the egg-eating habits of weasels" [2]. This technique copies a weasel behavior inside an egg. It sucks out an egg from inside and casual observers can't find anything inside. Therefore, "words or claims that appear substantial upon first look but disintegrate into hollow meaninglessness on analysis are weasels" (Example 6).

Another apt technique used to show the superiority of an advertised product is to use the 'we are different and unique' claim. This technique is the most known to the audience (Example 7). The uniqueness of the product is communicated to the audience by the usage of word combinations, such as 'there is nothing else like...', 'there is no other...' and words 'unique', 'extraordinary', 'different' etc [11].

Therefore, the language of advertising can be named a language of 'public-colloquial discourse', as is stated by Leech. If to summarize stylistic devices used in advertising, we can create ad phrase: employ creativity and reach perfectibility.

The language of poetry: the language of poetry and its form is created for its own sake. Poetic texts are created for pleasure and amusement, for thinking and joy. Thus a set of stylistic devices is used in the language of poetry for the description of "poetry substance imagined'. Poetry is a highly marked dis- course. Such devices as inversion, repetition, parallelism are widely used [2]. For example, 'a slow and stopping curve southwards we kept' [6].

Moreover, a wide range of lexical devices are used to 'make experiments' with the old lexis and createnew lexis: 'anyone lived in a pretty how town' [3]. Semantic devices, such as metaphor, simile, metonymy, etc are also used in poetry. For example, 'April is the cruelest month, breeding / Lilacs out of the dead land' [15].

Moreover, readers may be impressed by phonologically-hued poems, e.g. 'bird by snow and stir by still' [3].

The poem "Beauty" by John Mansfield is a romantic poem about happiness. A foreground of the poem implies a highly-emotional context reflected in metaphors ('the lady April bringing in the daffodils'; 'the dear red curve of her lips'), similes (windy hills; the soft warm April rain; slow old tunes of Spain) and onomatopoeia ('the old chant of the sea'). The language of the poem sounds like a song a man-inlove sings to her beloved lady. A deep emotional charge of the poem the author managed to transfer in a gradual, flowing, and tender manner. This refers to the characteristics of a romantic poem. Moreover, Mansfield refers to the marine theme and this helps his poem to sound like the waves of the sea. The romantic spirit of his poem may be proven by the following lines:

'I have seen the lady April bringing in the daffodils / Bringing the springing grass and the soft warm April rain'. What can be more romantic than the Spring? Mansfield embodies her beloved woman in the image of the Spring. Unlike Elliot, who described April as 'the cruelest month, breeding/ Lilacs out of the dead land' [15], Mansfield is more appealing for his readers and touch the romantic strings of a reader's soul.

Therefore, in the poetry as in a highly-marked context, various stylistic devices are used. It is possible to claim that poetry is one of the genres, saturated with numerous stylistic devices. The most distinct feature of poetry is the usage of words with figurative meaning, such as metaphors, similes etc. Omission of words, conversion, parallelism, repetition, amplification and many other stylistic devices are used to create a poetic form for the sake of the form [12]. Poetry introduces numerous neologisms created in the result of coinages, using conversion etc. Poetry reflects the usage of the most vivid and expressive stylistic devices [14]. Nevertheless, not only the form in poetry is important, but the reflection of the most appealing issues to a human soul.

The language of journalese: The language of journalese has many features in common with the language of advertising, considered above. Ads 
and newspapers appeal to the customers in a mass market. A concise form of newspaper stories should be highly informative. As a rule, readers of newspapers do not have enough time to read everything thoroughly. They have time to grasp pieces of the required information and that's all. A dualistic approach to the informative function of newspaper stories is an interesting issue for discussion. On the one hand, readers want to have rest from severe realities, but on the other hand, they want to have information about the horrors of our lives [13].

Noun-phrases 'squeezing' as much information as possible are common: e.g. Larger- than- life comedienne Joe Brand [10].

The structure of a newspaper story has a certain chronological structure. There are five main ele-

Appendix I

Example 1: "You can be sure if it's Westinghouse".

Example 2: "Great Lash greatly increases the diameter of every lash".

Example 3: "Take a bite and you'll think you're eating on the Champs Elysées".

Example 4: "Magnavox gives you more".

Example 5: "The perfect little portable for all around viewing with all the features of higher priced sets".

Example 6: "Helps control dandruff symptoms with regular use". The weasels include "helps control", and possibly even "symptoms" and "regular use". The claim is not "stops dandruff".

"Leaves dishes virtually spotless". We have seen so many ad claims that we have learned to tune out weasels. You are supposed to think "spotless", rather than "virtually" spotless.

Example 7: "There's no other mascara like it"; "Only Doral has this unique filter system".

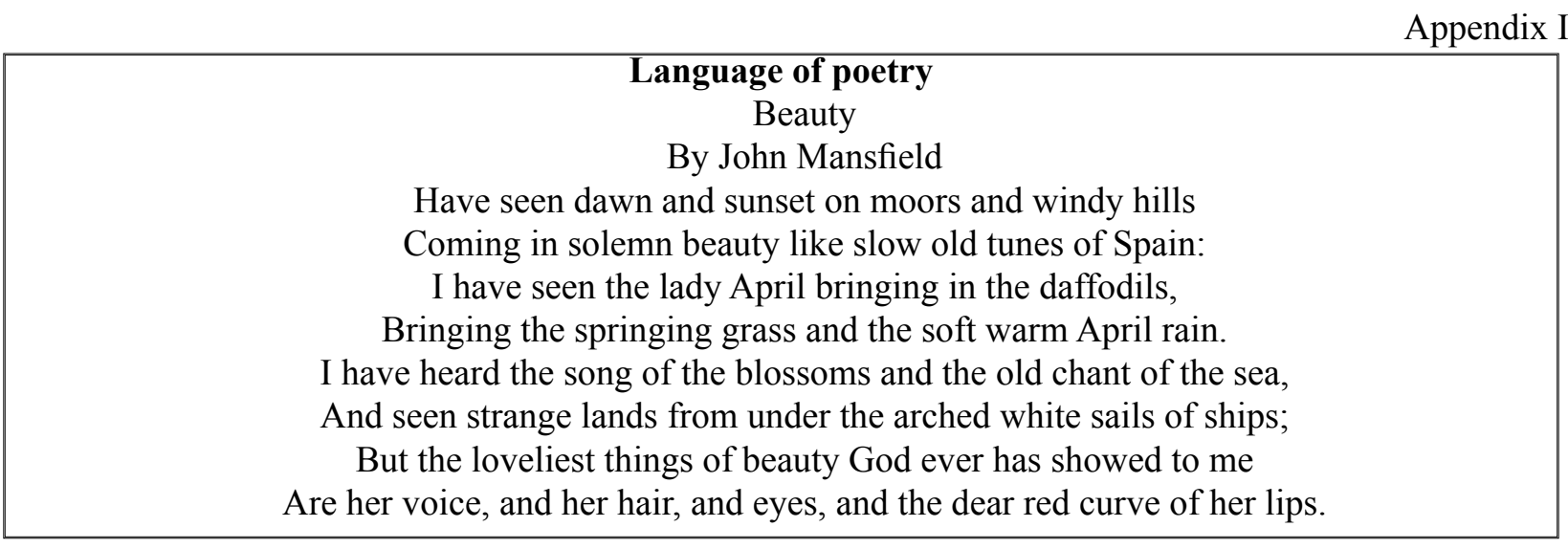

\section{A Double Dinosaur Discovery}

Language of journalese

Appendix III

Last December, two research teams working 2,000 miles apart in Antarctica made amazing discoveries. Each unearthed the fossilized remains of what is believed to be a new species of dinosaur. One is an herbivore, or plant eater, and the other is a carnivore, or meat eater. Working separately, the teams led by scientists James Martin and William Hammer found the fossils. "There we were, in the middle of Antarctica, talking to Bill about his find 2,000 miles away," Martin told TFK.

\section{FROZEN IN TIME}

Near Beardmore Glacier, Hammer's team found the bones of what they think is a plant-eating sauropod that lived 200 million years ago during the Jurassic Period. On the island off the Antarctica Peninsula, Martin and his team found the bones of a type of theropod, a group that includes the tyrannosaur. Each discovery will give scientists a new glimpse into the age of the dinosaurs. Any fossil find in Antarctica is rare, because bones and other remains are frozen and buried under many layers of ice. "We know very little about life in Antarctica from this particular time period," said Martin.

Excavating the fossils is just the beginning. The scientists will start a yearlong process to analyze the bits of teeth and bone. "It's a detective story," Martin says. "You take all these bits of evidence and reconstruct the past." (Sample Newspaper Story). 
ments: abstract-setting-complicating action-resolution-coda. The special attention of readers is attracted by a newspaper story 'abstract'. It combines the headline and the lead sentence. In Appendix III on the example of the newspaper story, it is seen that in the first two sentences of the first paragraph the authors grasp the attention of readers. Then he introduces a quotation to prove his claim and to underline that his story is important. A subhead used by the author organizes his story. Further on, the author describes the events, underlining their importance, and finally prognosticates a future development of the story (Appendix I- III).

Besides the structure of the story and the author's intention to grasp the readers' attention, it is very important to write an apt headline. The headline plays an even more important role than an abstract. Puns or alliteration are often used stylistic devices in headlines to attract the attention of readers. For example, the headline Burning questions on tunnel safety unanswered belongs to the newspaper article about possible fires in the Channel tunnel [10]. 'Burning questions' is the pun because the questions concern fires. From another perspective, 'burning question' has a meaning of an important question.
Another headline, Science friction is assigned to the article about the polemics between British intellectuals and the British government on the matter of mad cow disease [10]. The word 'friction' means tension or disagreement among people; in this case, 'friction' refers to science fiction.

Therefore texts of newspapers play an informative function via a variety of stylistic device usage. Structural peculiarities of the newspaper stories combined with stylistic devices used to communicate the author's intentions to the readers. An important role of a newspaper text is to entertain and amuse and at the same time provide readers with information.

Conclusions. The English language speakers focus on both formalistic structures and theoretical underpinnings the way they would build a house of bricks. From the first layer of word-formation elements, suffixes and prefixes to the highest level of texts and discourse, language users develop their linguistic competence on formalistic and structural bases, and then, they add semantics, stylistics, and pragmatics to enliven their communication. Within a myriad of contexts, the English language, its anthropocentric basis and further stylistic representation are related thus creating a diverse linguistic patchwork.

\section{REFERENCES:}

1. Bovee C., Arens W. Contemporary Advertising. Boston : McGraw-Hill/Irwin, 2006. 614 p.

2. Collins Cobuild Advanced Learner's English Dictionary. 2006. URL: https://www.amazon.com/CollinsCOBUILD-Advanced-Learners-Dictionary/dp/000 7210132 (дата звернення 13.02.2021).

3. Cummings E. URL: https://scholar.google.com/citations?user=09AlkJ OAAAAJ\&hl=en (дата звернення 11.02.2021).

4. Gibson E. How Efficiency Shapes Human Language. URL: https://www.researchgate.net/ publication/332515557_How_Efficiency_Shapes_Human_Language (дата звернення 11.02.2021).

5. Goody E. 'Stone Age Sociology' - Or Sociology of Early Language-Using Society? Journal of the Royal Anthropological Institute, 2005. Vol. 11 (3), 585 p.

6. Larkin P. The Whitsun Weddings'. URL: https://www.poetryfoundation .org/poems/48411/the-whitsunweddings (дата звернення 15.02.2021).

7. Lehr F.R. The Sequence of Speech-Sound Acquisition in THE LETTER PEOPLE Programs. URL: https://www.abramslearningtrends.com/sites/default/files/089551.pdf (дата звернення 13.02.2021).

8. Lewis D. Language and Languages. 1975. URL: https://oxford.universitypressscholarship.com/view/10.1093/ 0195032047.001.0001/acprof-9780195032048 (дата звернення 14.02.2021).

9. Lock $A$. The role of gesture in the establishment of symbolic abilities: continuities and discontinuities in early language development. URL: http://www.massey.ac.nz/ alock/virtual/sherman.htm (дата звернення 12.02.2021).

10. Saks N. Determinants of CEO Compensation before and after the Financial Crisis. Modern Economy, 2010. Vol. 7, № 12. P. 2099-2138.

11.Schrank F. 2020. URL: https://imslp.org/wiki/Category: Schrank,_Fr anz_von_Paula (дата звернення 15.02.2021).

12. Semino E. Language and World Creation in Poems and Other Texts. C. : Longman, 1997. 273 p.

13. Short M. Discourse Analysis in Stylistics and Literature Instruction. Cambridge University Press, 1989. P. 1471-6356.

14. Simpson P. Politeness phenomena in lonesco's The lesson. Language, discourse and literature. London : Unwin Hyman. 1989. P. 171-193. Google Scholar

15. T. S. Eliot "The Waste Land". URL: https://www.poetryfoundation. org/poems/47311/the-waste-land (дата звернення 15.02.2021). 